\title{
Current and Potential Contribution of the Colombian Ministry of Defense to the National River Master Plan and the Accomplishment of the Sustainable Development Goals through COTECMAR
}

DOI: https://doi.org/10.25043/19098642.203

Edwin Giovanny Paipa Sanabria ${ }^{1}$ Henry Murcia Fernández ${ }^{2}$

\begin{abstract}
This article aims to present the current and potential contributions made by the Ministry of National Defense through the Corporation of Science and Technology for the Development of the Naval Maritime and River Industry - COTECMAR - and the National Navy to the River Master Plan and to the fulfillment of the Sustainable Development Objectives defined in the United Nations Agenda 2030. To this end, the contributions that have been generated so far are explored, such as the case of the river piers, the pilot project for the River Information System (RIS) and the integration of the Small Vessels Committee that is essential for the operation of a future National Port Agency. Likewise, potential solutions that can operate to meet regional needs in health, education, transport, tourism, etc. are highlighted. Finally, the opportunity to integrate the ODS, the development plans and the River Master Plan in the structuring of interregional project portfolios focused on closing social gaps in Colombia is foreseen.
\end{abstract}

Key words: River Master Plan, Sustainable Development Goals, Gap, Project Portfolio.

\section{Resumen}

El presente artículo tiene como objetivo presentar los aportes actuales y potenciales realizados por parte de Ministerio de Defensa Nacional a través de la Corporación de Ciencia y Tecnología para el Desarrollo de la Industria Naval Marítima y Fluvial - COTECMAR - y la Armada Nacional al Plan Maestro Fluvial y al cumplimiento de los Objetivos de Desarrollo Sostenible definidos en la Agenda 2030 de las Naciones Unidas. Para esto son explorados las contribuciones que hasta ahora han sido generadas, como el caso de los embarcaderos fluviales, el proyecto piloto para el Sistema de Información Fluvial (SIF) y la integración del Comité de Pequeñas Embarcaciones que resulta esencial para la operación de una futura Agencia Nacional de Puertos. Igualmente se destacan soluciones potenciales que pueden operar para atender necesidades regionales en temas de salud, educación, transporte, turismo, etc. Finalmente se vislumbra la oportunidad para integrar los ODS, los planes de desarrollo y el Plan Maestro Fluvial en la estructuración de portafolios de proyectos interregionales enfocados en el cierre de brechas sociales en Colombia.

Palabras claves: Plan Maestro Fluvial, Objetivos de Desarrollo Sostenible, Brechas, Portafolio de Proyectos.

Date Received: March $2^{\text {nd }} 2020$ - Fecha de recepción: Marzo 2 de 2020

Date Accepted: June 30 2020 - Fecha de aceptación: Junio 30 de 2020

${ }^{1}$ Designer at COTECMAR - Design and Engineering Office. Email: epaipa@cotecmar.com
${ }^{2}$ Researcher at COTECMAR - Science, Technology and Innovation Management Office. Email: hmurcia@cotecmar.com 


\section{Introduction}

The Ministry of National Defense, based on its Strategic Plan for the Defense and Security Sector $2016-2018,{ }^{1}$ is in a process of adaptation to the country's needs in the post-conflict period. This tool has been built under the guidelines of the National Development Plan (PND) 2014-2018 "All for a new country". This is ${ }^{2}$ based on the development of three pillars: Peace, Equity and Education, as well as six cross-cutting themes: 1) Competitiveness and strategic infrastructure, 2) Social mobility, 3) Transformation of the countryside, 4) Good governance, 5) Green growth and 6) Security. Based on these strategies, a governance scheme is proposed that will strengthen the presence of the state throughout the national territory and build its legitimacy "from and for the territories.

Thinking about the structuring of strategic programs to close the gaps - country, it is important to consider that the mentioned National Development Plan (2014 - 2018) became a pioneer by framing its goals within what was agreed before the United Nations with the signing of the Agenda $2030^{3}$ where the bases and purposes of the Sustainable Development Goals are mentioned.

In this way, considering the previous historical reference, all the ministerial institutions in Colombia have adopted the bases proposed in the SDG (United Nations, 2017) and the NDP to contribute to closing the country's gaps. Thus, the National Ministry of Defense and its military industries, including COTECMAR, have been making significant efforts in this regard.

To frame NMD's contribution through COTECMAR in the guidelines provided by the NDP 2014-2018, Fig. 1 shows the alignment of the NDP objectives with the strategic objectives of the defense and security policy 2015-2018.

\footnotetext{
1 (Ministry of National Defense - Colombia, 2016).

2 (National Planning Department - DNP, 2015).

3 Signed at the United Nations headquarters (New York) on 27 September 2015 by 193 countries that agreed on commitments to sustainable development.
}

Considering this articulation of efforts (PND PESDS $^{4}$ ), taking into account that one of the objectives defined by the Ministry of National Defense is to contribute to the improvement of competitiveness and strategic infrastructure and social mobility; and highlighting the vision of the Ministry of Transport of Colombia expressed in the River Master Plan $2015^{5}$. This article presents the contributions that the Corporation of Science and Technology for the Development of the Naval, Maritime and River Industry - COTECMAR -, "main Center of Technological Development of the National Navy ${ }^{6 "}$ and potential advisor of the sub-directorate of Research and Development in Science and Technology of the National Agency of Navigation and Ports - ANP', has generated and has the potential to propose, based on the goals established in development plans, such as the "Pact for Colombia, Pact for Equality 2018-2022" which is currently being structured through citizen participation $^{8}$.

For this, it is important to consider the five components that have been identified to determine the actions that will fulfill the specific objectives of the River Master Plan 2015. Fig. 2.

Of the components highlighted in Fig. 2, this paper will only emphasize the current and potential contributions to a) River and Connection Infrastructure, b) Operation, c) promotion and institution.

\section{Contributions to the components of the River Master Plan}

In view of the new political-military scenario in Colombia and the process of adaptation to the

\footnotetext{
Strategic Plan for the Defence and Security Sector.

5 Developed by the Ministry of Transport of Colombia, the National Planning Department (DNP), ARCADIS and JESYCA S.A.S, determines the vision of the country in the search for a more competitive, clean, safe and social river transport.

6 According to the Naval Strategic Plan 2015 -2018 (Colombian National Navy, 2016).

7 According to the River Master Plan 2015, ANP is the Agency that is projected to create for the institutional and centralizing order of the functions and responsibilities that are disintegrated in different entities that today try to attend the river transport system.

${ }^{8}$ As can be seen in the platform https://www.pactoporcolombia.gov.co/ pnd, created by the current national government, for citizen participation in the construction of the new National Development Plan.
} 
Fig. 1. Alignment of NDP objectives with the Security and Defense Strategy - Source (Ministry of National Defense Colombia, 2016).

\begin{tabular}{|c|c|c|c|c|}
\hline $\begin{array}{c}\text { Transversal } \\
\text { Strategy NDP }\end{array}$ & $\begin{array}{c}\text { NDP } \\
\text { Objectives }\end{array}$ & $\begin{array}{l}\text { NDP Strategic } \\
\text { guidelines }\end{array}$ & NDP Actions & $\begin{array}{c}\text { Objectives of the defense and } \\
\text { security policy "all for a new } \\
\text { country" }\end{array}$ \\
\hline \multirow{10}{*}{$\begin{array}{l}\text { Security, } \\
\text { justice and } \\
\text { democracy for } \\
\text { the construction } \\
\text { of peace }\end{array}$} & \multirow{10}{*}{$\begin{array}{l}\text { Promote } \\
\text { security and } \\
\text { defense in } \\
\text { the national } \\
\text { territory }\end{array}$} & \multirow{6}{*}{$\begin{array}{l}\text { Modernize and } \\
\text { strengthen security } \\
\text { and defense } \\
\text { institutions }\end{array}$} & Human capital & \multirow{5}{*}{$\begin{array}{l}\text { Objective } 06 \text { : } \\
\text { Continuously transform and } \\
\text { modernize the Defense Sector, } \\
\text { as well as improving education, } \\
\text { welfare, morale and safety } \\
\text { legal as well as financial } \\
\text { management, budgetary and } \\
\text { contractual force Public }\end{array}$} \\
\hline & & & Capabilities planning & \\
\hline & & & $\begin{array}{l}\text { Sustainability and efficiency } \\
\text { of sector spending }\end{array}$ & \\
\hline & & & $\begin{array}{l}\text { Financial and contractual } \\
\text { management }\end{array}$ & \\
\hline & & & Human rights & \\
\hline & & & $\begin{array}{l}\text { A more competitive social } \\
\text { and business defense group } \\
\text { (GSED) }\end{array}$ & $\begin{array}{l}\text { Objective 09: } \\
\text { Put at the service of national } \\
\text { development, commercial, } \\
\text { industrial and agricultural } \\
\text { business capabilities of Defense } \\
\text { Sector }\end{array}$ \\
\hline & & \multirow{3}{*}{$\begin{array}{l}\text { Contribution of } \\
\text { the security and } \\
\text { defense sector to the } \\
\text { development of the } \\
\text { country }\end{array}$} & Risk management & $\begin{array}{l}\text { Objective 08: } \\
\text { Make available to the } \\
\text { Colombian State the capacities } \\
\text { of the Public Force to mitigate } \\
\text { the effects of climate change, } \\
\text { respond to natural disasters and } \\
\text { protect ecosystems }\end{array}$ \\
\hline & & & $\begin{array}{l}\text { Contribution to territorial } \\
\text { consolidation }\end{array}$ & \multirow{2}{*}{$\begin{array}{l}\text { Objective 03: } \\
\text { Contribute to the modernization } \\
\text { of rural society linking } \\
\text { the Defense Sector to the } \\
\text { interventions made by the } \\
\text { National Government } \\
\text { for development }\end{array}$} \\
\hline & & & $\begin{array}{l}\text { Science, technology and } \\
\text { innovation }\end{array}$ & \\
\hline & & $\begin{array}{l}\text { Disarmament, } \\
\text { demobilization and } \\
\text { reintegration }\end{array}$ & $\begin{array}{l}\text { Strengthening } \\
\text { demobilization campaigns, } \\
\text { focusing efforts on those } \\
\text { regions where these groups } \\
\text { concentrate their actions }\end{array}$ & $\begin{array}{l}\text { Objective } 01 \text { : } \\
\text { Contribute with the capacities } \\
\text { of the Public Force to end the } \\
\text { conflict and peace building }\end{array}$ \\
\hline
\end{tabular}

Fig. 2. Components of the River Master Plan Source: Ministry of Transport, National Planning Department, ARCADIS, JESYCA S.A.S (2015).

Main Objective

\section{Specifics Objectives}

\section{More competitive, clean, safe and social river transport}

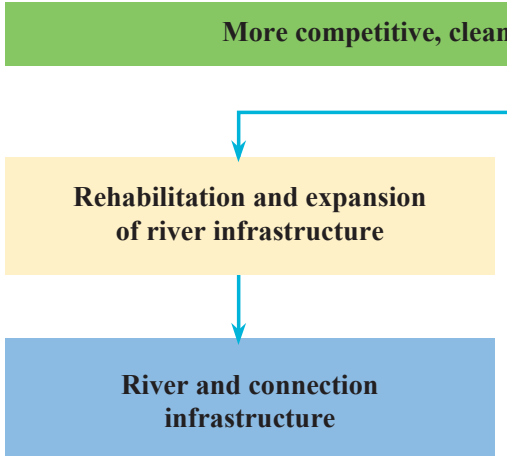

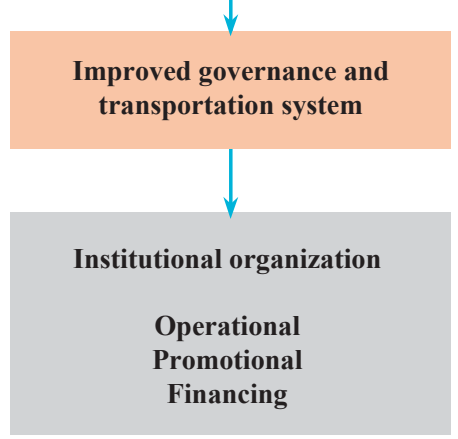


Fig. 3. Problem tree. Source: COTECMAR

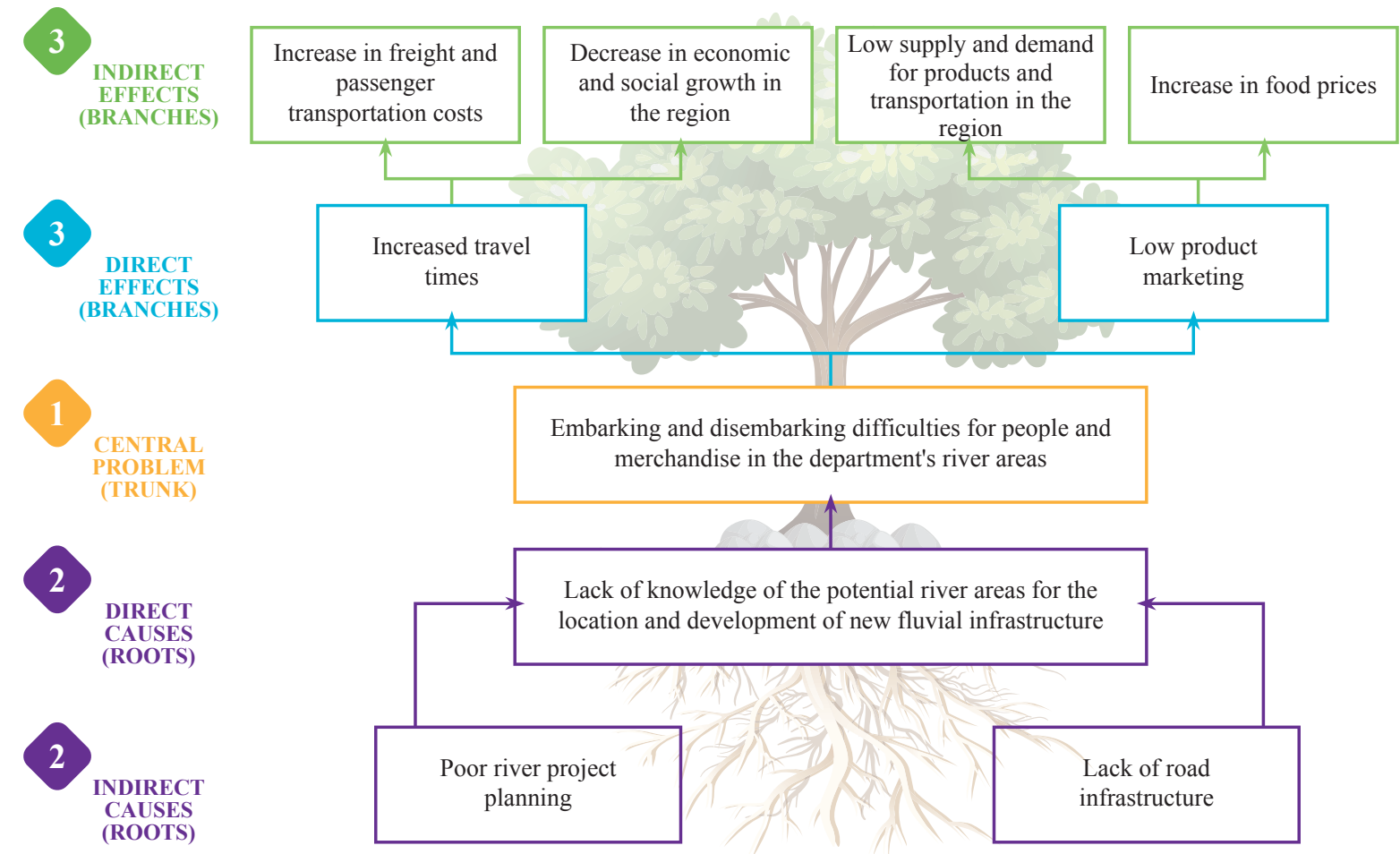

country's post-conflict needs, the Military Forces play a predominant role where it is necessary to put all their capabilities at the service of the nation for the improvement of transport and river infrastructure.

This is how COTECMAR acquires special attention due to its role as a dynamizer of the naval, maritime and fluvial industry, and its contribution in the resolution of the country's challenges from its efforts in science, technology and innovation.

For this reason, the following highlights the contribution of the Ministry of Defense through COTECMAR, for the components of the River Master Plan that were previously specified.

River and Connection Infrastructure Component

This component is aimed at fulfilling two fundamental objectives: 1. Improving the projected demand for transport for cargo and passengers and 2 .
For this, the Ministry of National Defense, together with COTECMAR and the National Navy, through a project focused on preliminary technical ${ }^{9}$ studies, design, manufacture, assembly, installation and commissioning of 12 river piers in the rivers of Inírida, Vaupés, Vichada, Uva, Caquetá, Baudó, Atrato, Orinoco and Guaviare; managed to positively impact the issue of infrastructure and connection for the populations near the rivers of the mentioned regions.

This project was constituted as a solution to the identified problem (Fig. 3), formulated as:

"Difficulties in loading and unloading people and goods in the riverine areas of the departments".

The solution, river piers, with their technical characteristics (Fig. 4), such as the one delivered in the municipality of Solano - Caquetá, allowed the execution of a new study $(M D N, 2018)$ for the installation of another 29 river devices in the department of Chocó, in geographical points

\footnotetext{
${ }_{9}$ (Ministry of National Defence, 2018).
} 
Fig. 4. Wharf components.

\section{COMPONENTS}

1. Pontoon or modules

2. Gate or walkway

3. Railings

4. Cleats (boat mooring)

5. Simple bit (ground tie)

6. Maintenance Access

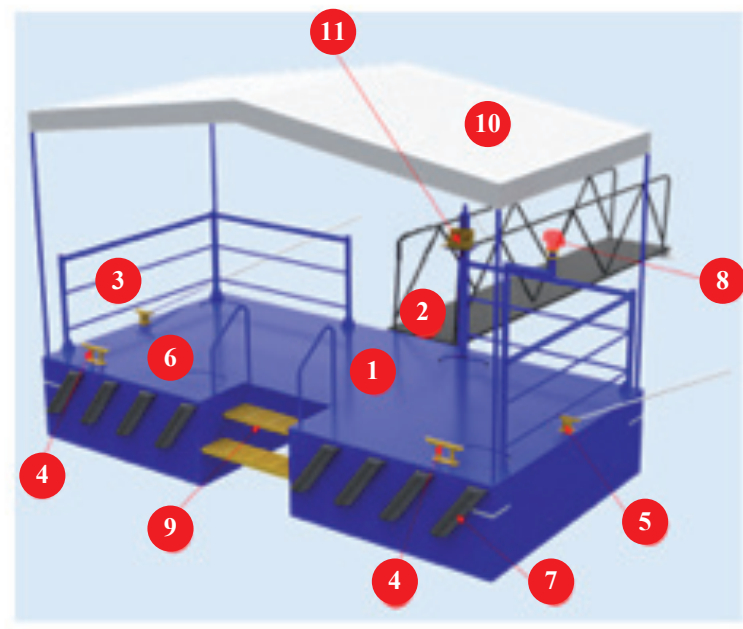

Fig. 5. Delivery of the Embarcadero - Municipality of Solano (Caquetá).

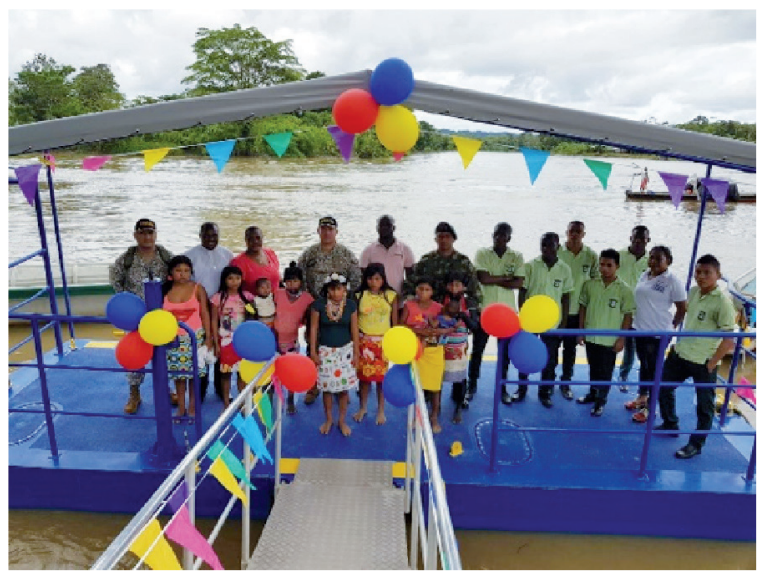

along the banks of the Atrato, San Juan and Baudó rivers.

Considering that the mentioned geographical points in the department of Chocó share the same problematic of those places in which the installation of the fluvial piers was already achieved, and taking into account the experience of the NMD and
COTECMAR on the component of infrastructure and connection of the Fluvial Master Plan, it is expected to be able to take the proven solution to these riverside populations with the construction of the piers.

In addition to this, COTECMAR has envisioned other potential contributions to river development, in which the concept of modularity has become an added value for the versatility required by solutions for the use of rivers in Colombia. This has allowed the generation of multifunctional Naval Device projects with different configurations adapted to the specific needs of the riparian populations, which can be sent to any point in the country.

The following potential solutions (Fig. 6 to 12) have been designed for embarking and disembarking of passengers and cargo, river water intake and conveyance, migration control posts, military control stations, training, health posts and institutional use (registry offices, notaries, among others).

Fig. 6. Migratory River Post.

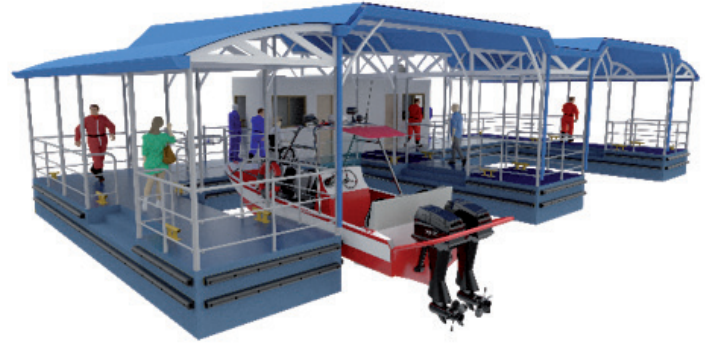

Fig. 7. Personnel and light cargo transport wharf.

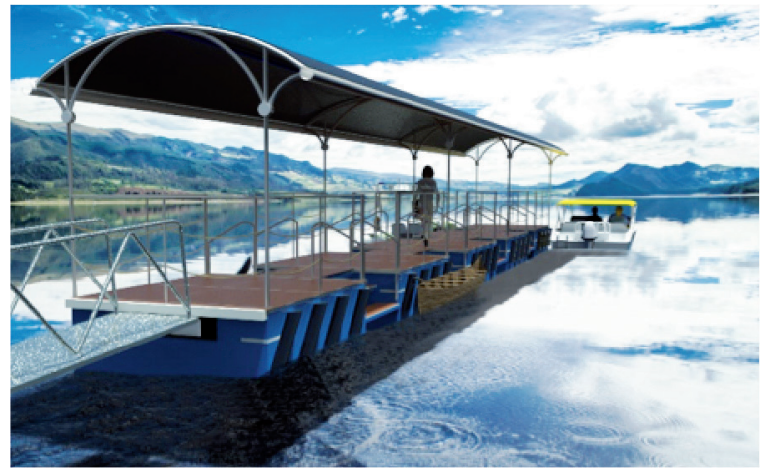


Fig. 8. Water collection station.

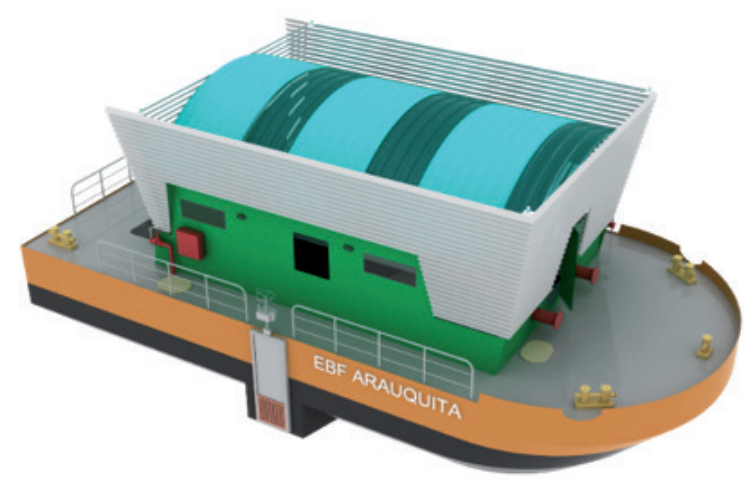

Fig. 9. Military Area Control Floating Station.

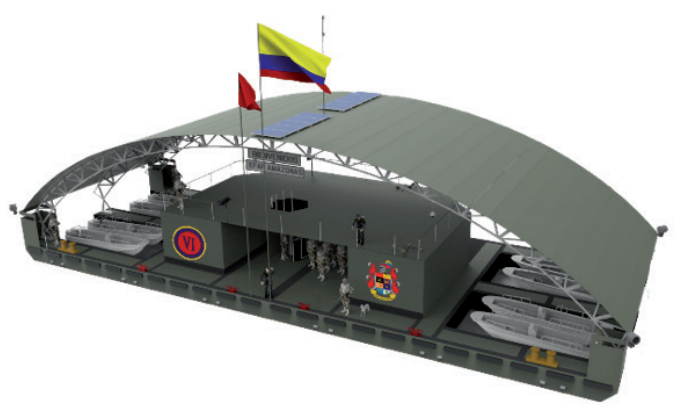

Fig. 10. Barge for transporting vehicles.

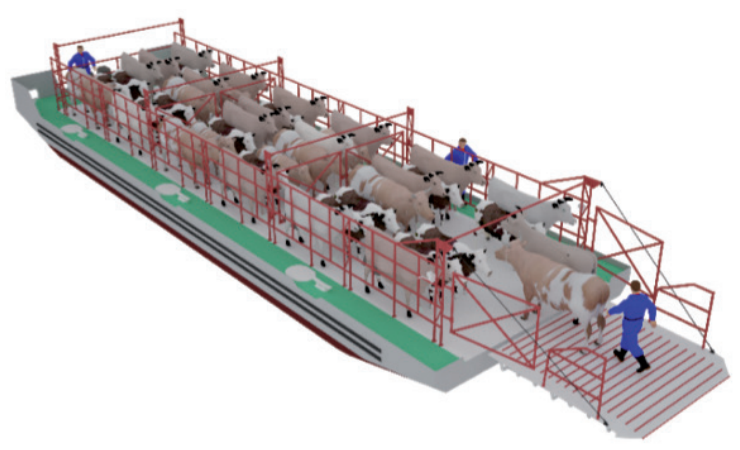

Fig. 11. Barge for transporting vehicles.

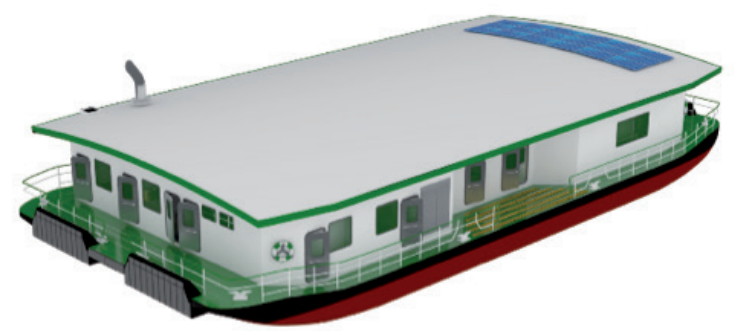

Fig. 12. River Control Station.

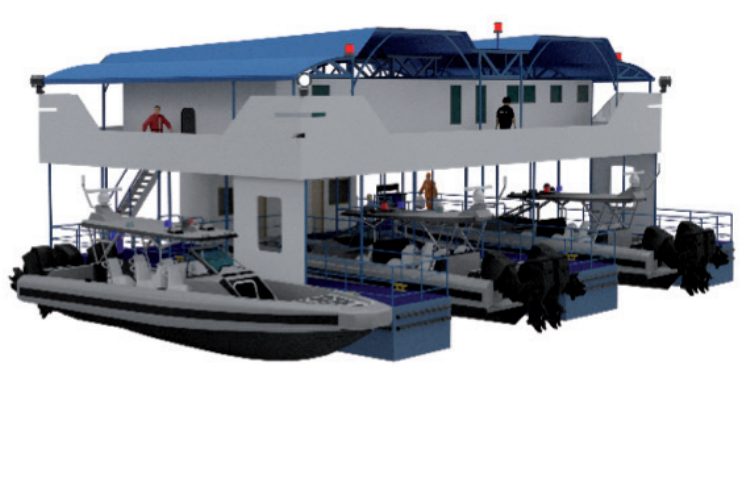

Component Operation

The existing and potential contribution by NMD through COTECMAR in terms of the operational component is the design, construction and maintenance of the country's river fleet, in order to provide a portfolio of solutions for the standardization and renewal of vessels that have largely passed their time of obsolescence.

The projects developed are focused on the following areas: cargo and passenger transport, health, disaster relief, tourism, social development in remote areas, environmental preservation, security of inland water bodies and education.

The figs. below, from number 13 to 24, correspond to the new products that COTECMAR can offer to promote the use and exploitation of the river arteries through the potential vessels that can operate throughout the country.

Fig. 13. River Pusher for the Magdalena River.

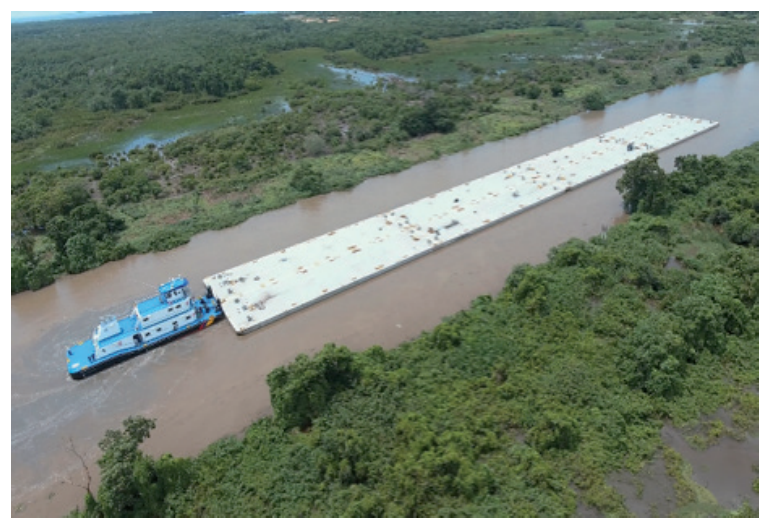


Fig. 14. 35-passenger boat.

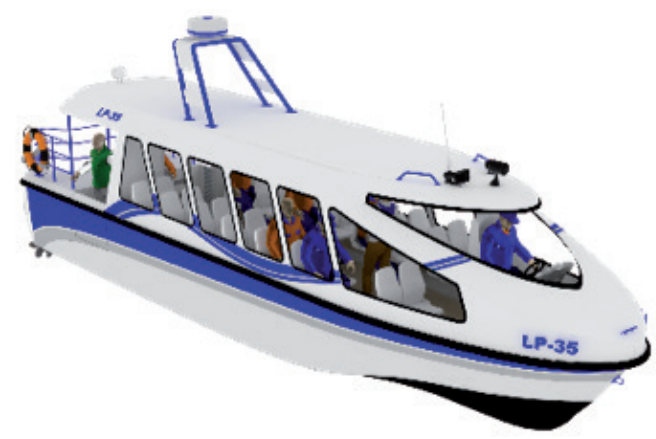

Fig. 15. Logistic Support and Health boat.

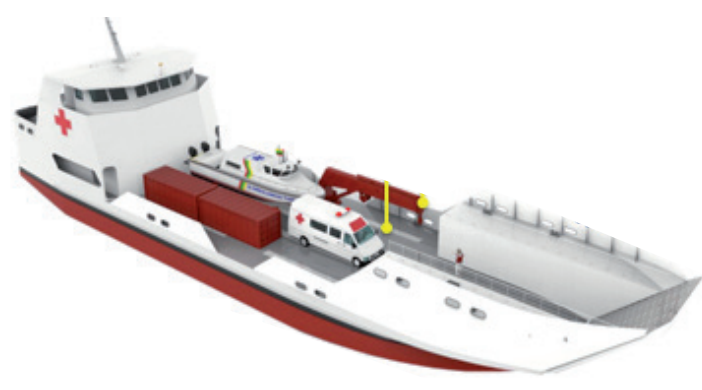

Fig. 16. Ambulance boat.

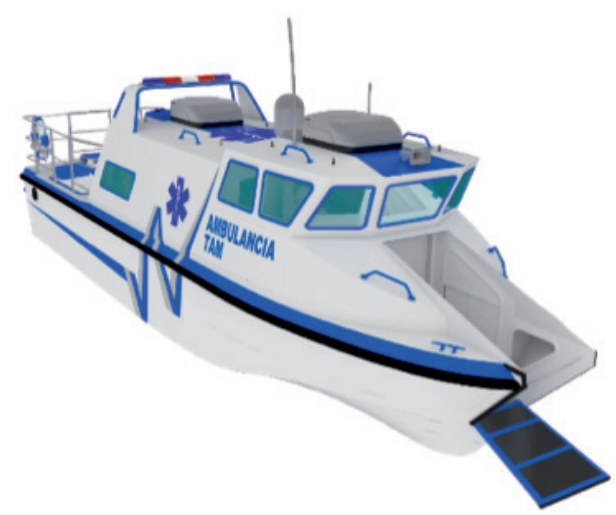

Fig. 17. Rescue boat.

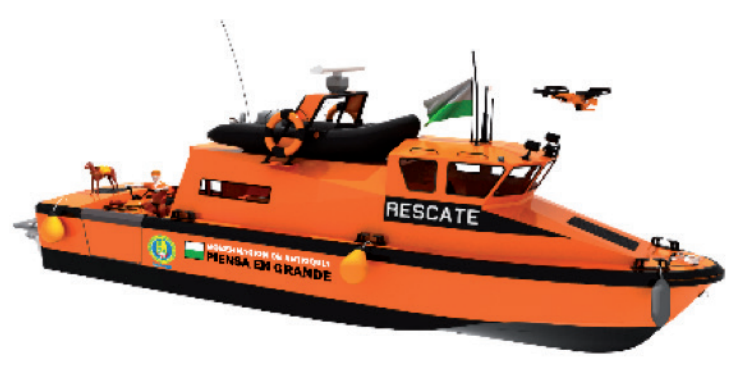

Fig. 18. Fireboat.

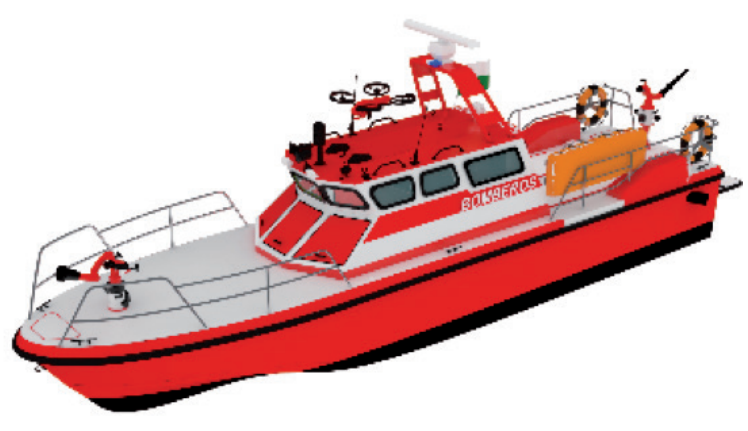

Fig. 19. Ecotourism vessel.

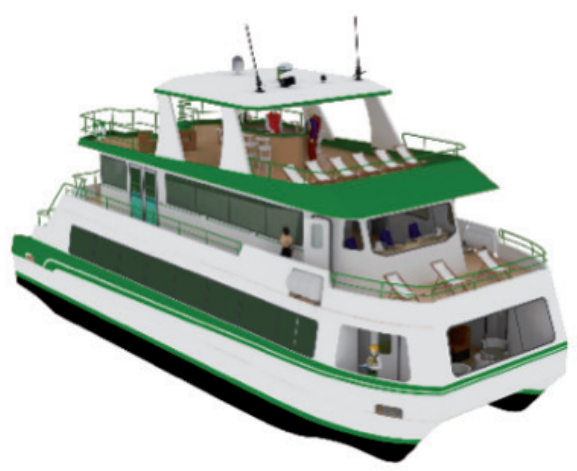

Fig. 20. River Barge.

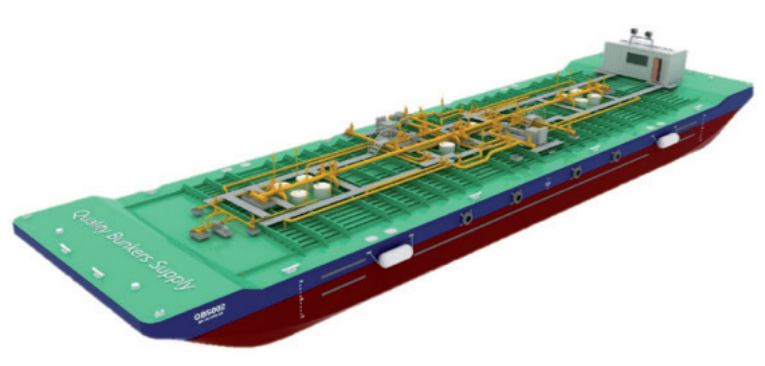

Fig. 21. Social Action Platform.

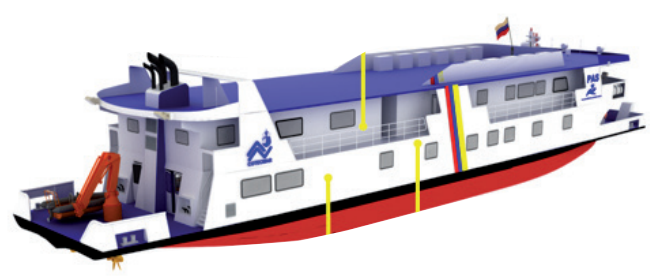


Fig. 22. Pusher and social action modules.

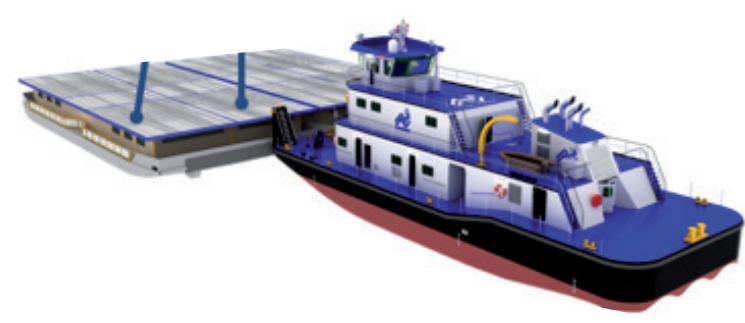

Fig. 23. Inter-institutional Immediate Care Center.

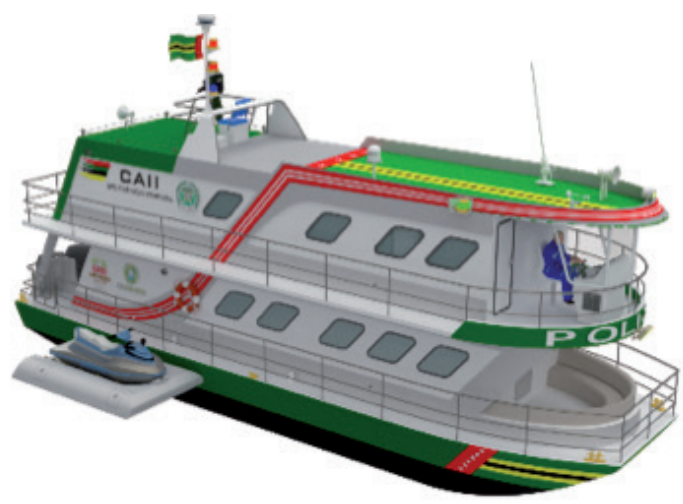

Fig. 24. Restaurant - bar boat.

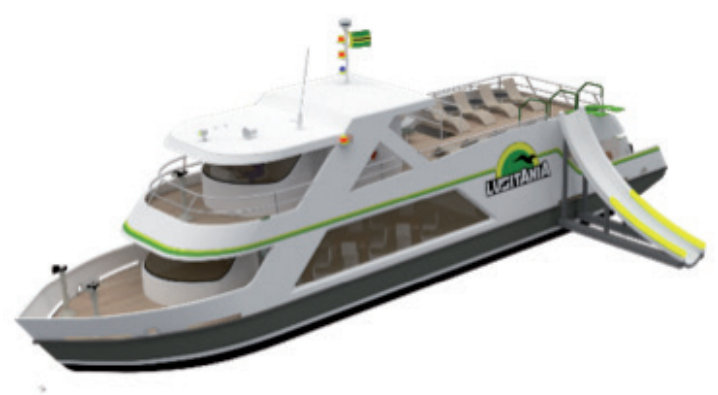

Promotional and Institutional Component

As can be seen in the River Master Plan (DNP, Ministry of Transport, ARCADIS, \&JESYCA S.A.S, 2015) In Colombia, river transport has not been strengthened in its operation due to duplicity and gaps in interaction by state agencies, generating difficulties in the implementation, control and policy among the entities.
The lack of academic programs specialized in water infrastructure, as well as the deficiency found in technical and economic regulation, are key factors that generate the need to revive ${ }^{10}$ the Directorate General of Navigation and Ports through a new organizational structure as the National Ports Agency (Fig. 25) that is proposed under the River Master Plan 2015.

For this reason (structuring of the ANP ${ }^{11}$ ) and under the needs of making the Colombian Technical Standards-NTC for small vessels and disseminate the river regulations in order to create tools to this new body, is created under the leadership of the Colombian Institute of Technical Standards and Certification-ICONTEC the committee 255 of small vessels, which has as main members the Ministry of Transport, the Directorate General of Maritime, COTECMAR and Eduardoño, as technical and operational advisers provide the requirements either directly or through references to existing international standards.

At this point, it is pertinent to make a parenthesis on the Colombian Technical Standards. The NTC are created to support manufacturers, government, users, consumers, research centers, associations and professional groups, seeking to generate benefits such as:

- The removal of trade barriers.

- Facilitating technological cooperation.

- Providing unambiguous and effective communication.

- Criteria unification.

- Optimal use of resources.

- Protection of the environment.

- Consolidating the organizational experience.

For the year 2018, the ratification (see validation process in Fig. 26) of five vital norms for the standardization of small crafts, by the committee 255 has been projected (where COTECMAR is technical advisor) taking as central axis the construction of the hull and the piercing of the ships and devices destined to the fluvial operation.

\footnotetext{
10 According to (DNP , Ministry of Transport , ARCADIS, \& JESYCA S.A.S, 2015)

${ }^{11}$ National Ports Agency
} 
Fig. 25. Proposed structure for the National Ports Agency.

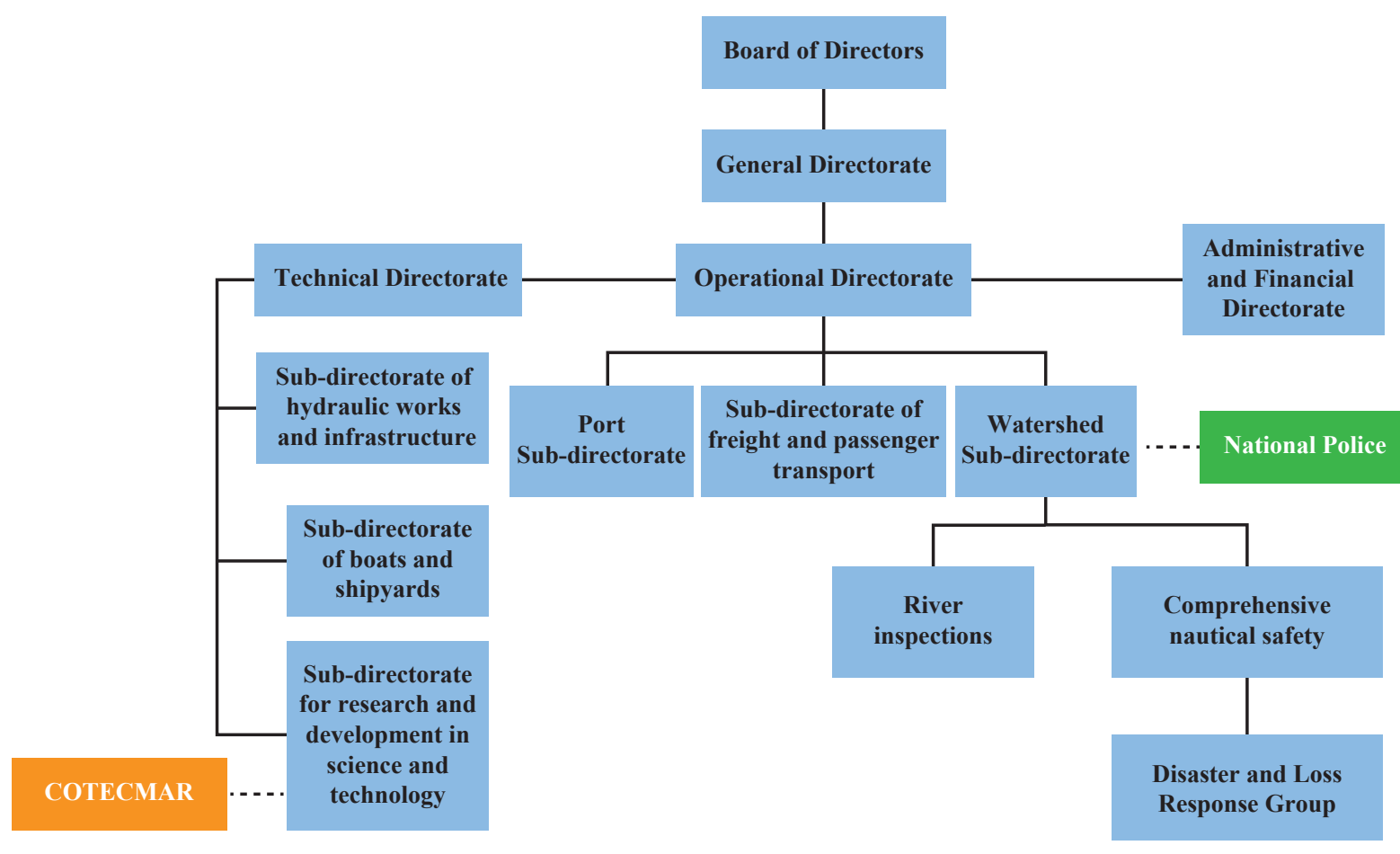

Fig. 26. Standards Validation Process - ICONTEC.

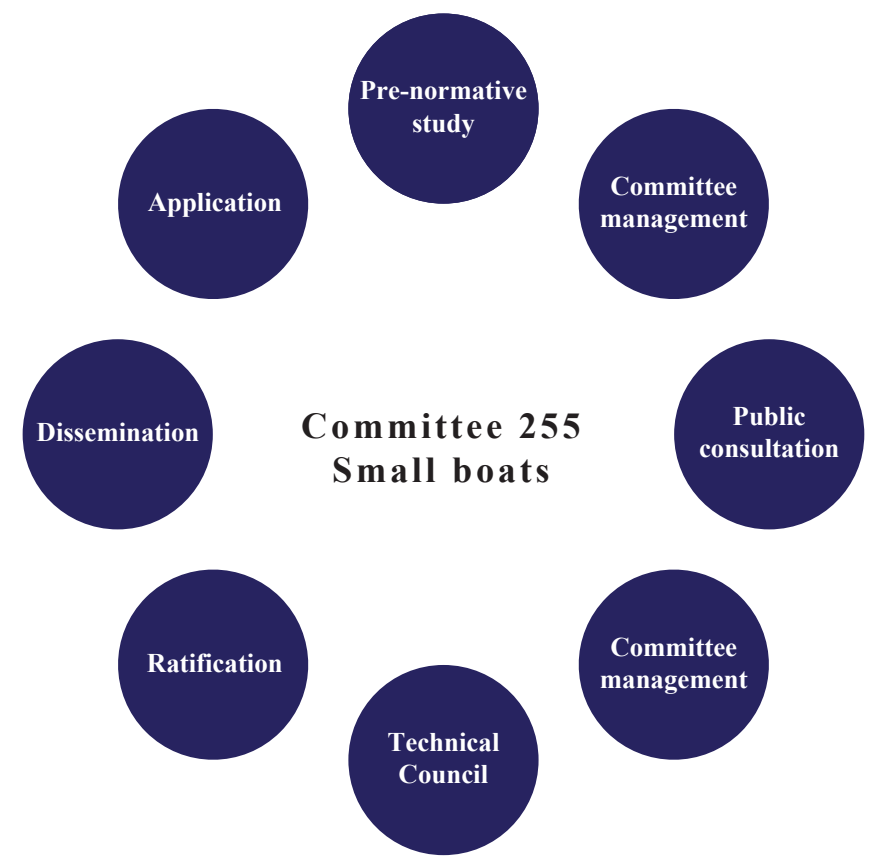

The following are the standards that are in the - Part 1 Thermosetting resins, reinforced fiber public consultation stage: glass. 
- Part 2 Core materials for sandwich construction, embedded materials

- Part 3 Materials: Steel, aluminum alloys, wood, other materials

- Part 4 Workshop and manufacturing.

- Part5 Design stresses for fixture determination in monohulls.

In this way, from what has been presented, it can be inferred that COTECMAR has contributed from the present in the promotional and institutional component to foment the navigability in the rivers of the country, through its participation in the "Committee of Small Boats" for the creation of norms that will become tools for the future National Agency of Ports. Likewise, in the future it is potentially projected to be an advisory body to the sub-directorate of Research, Development and Innovation for the structure proposed by ${ }^{12}$ ARCADIS and JESYCA S.A.S in their report to the Ministry of Transport and the National Planning Department.

\section{The River Traffic Control and Safety System - RIS}

In addition to the current and potential contributions presented in the previous section, another contribution of the Ministry of National Defense to the promotion of navigability in Colombia has been made through the National Navy and COTECMAR, articulating efforts with the Ministry of Transport, to launch the initiative to create a pilot project for a River Traffic Control and Safety System on the Magdalena River in order to provide a systematic management tool capable of processing data such as basic contact information of managers and operators, water levels, river traffic information, nautical charts, among others, to regulate and control the movements of vessels on the river.

This pilot project (see Fig. 27 sites with RIS ${ }^{13}$ ) should not be considered in isolation from the country's needs, but rather as part of a program

\footnotetext{
${ }^{12}$ The National Ports Agency.
}

${ }^{13}$ River Information System. of the Ministry of Transport with the objective of developing river transport in Colombia, which includes updating regulations, the national river register ${ }^{14}$ and structuring a bill to issue the National Code of River Traffic.

Fig. 27. Intervened sites for RIS project implementation.

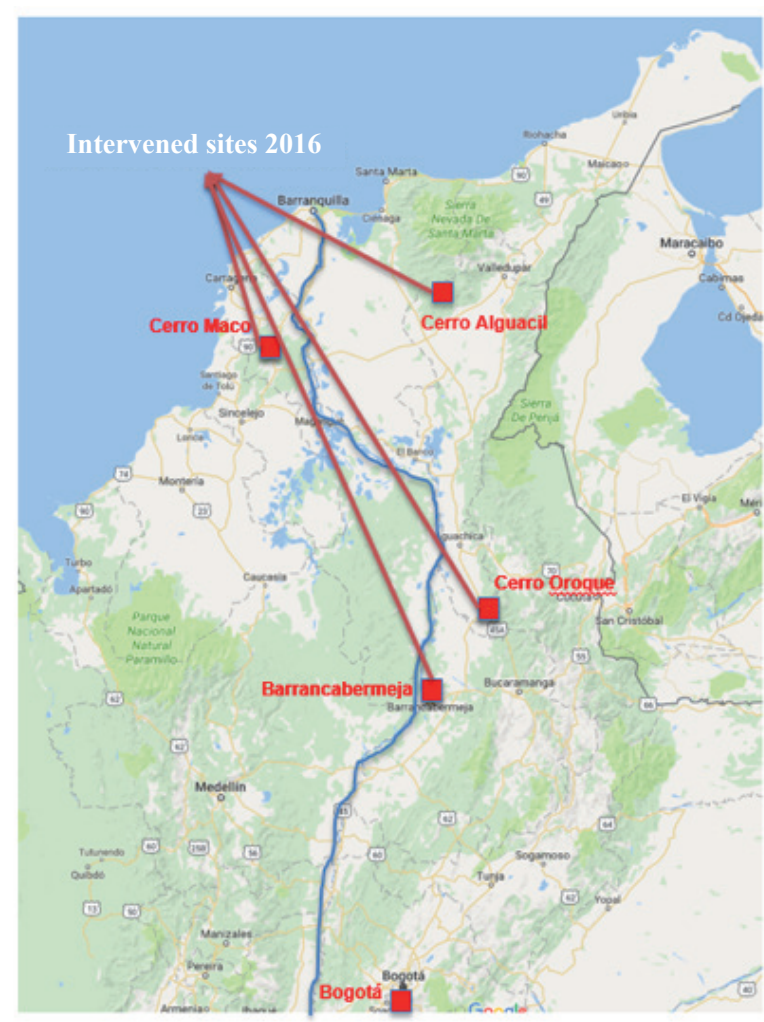

With the implementation of this pilot project, the following was achieved:

- Determination of the functional requirements and elaboration of technical specifications required to satisfy the identified operational capacities.

- Definition of the configuration of the basic architecture of the system and selection of the effective technological alternative.

- Installation and testing of the system.

If the benefits of this pilot project and its functionality are analyzed, it is possible to say that this project can be framed within the contributions

${ }^{14}$ In which information will be taken to all companies. 
that have been generated in the country within the Operational Component (section 2.2) that the River Master Plan contemplates, by emphasizing that the River Information System will favor the development of transport operations in a safe manner in the rivers of Colombia.

\section{Opportunity for Gap Closure - Sustainable Development Goals}

Up to this point, emphasis has been placed on the contributions that COTECMAR and the National Navy, on behalf of the Ministry of Defense, have generated for the promotion of a more competitive, clean, safe and social river transport in accordance with what is set out in the River Master Plan 2015.

The focus of this paper will be on the opportunities generated by the River Master Plan to impact the fulfillment of the Sustainable Development Goals adopted by Colombia before the United Nations, for the structuring of its Development Plan, based on the construction of interregional projects.

The River Master Plan, as indicated throughout this writing, is oriented towards the promotion of a more competitive, clean, safe and social river transport. However, if there is a good understanding of the commitments acquired by the country through the adoption of the Sustainable Development Objectives, it is possible to determine that the purpose set out in the FMP ${ }^{15}$ is directly related to SDG 9 given that it is focused on:

a) Building resilient infrastructure.

b) Promoting inclusive and sustainable industrialization.

c) Encouraging innovation.

In this sense, and given the FMP - SDG relationship, the development of the projects and strategies proposed for the promotion of river transport in the country will have an impact on the

${ }^{15}$ River Master Plan. health, transport, education and social promotion sectors, as a reflection of the fulfillment of specific goals established in the following manner:

\section{Health sector:}

- SDG 1: Ending Poverty in All Its Forms Worldwide.

- SDG 2: Ending hunger, achieving food security and improving nutrition, and promoting sustainable agriculture.

- SDG 3: Ensuring healthy living and promoting the well-being of all people at all ages.

\section{Transport sector:}

- SDG 11: Making Cities and Human Settlements Inclusive, Safe, Resilient and Sustainable.

\section{Education Sector:}

- SDG 4: Ensuring inclusive and equitable quality education and promoting learning opportunities for all.

\section{Promotion and Development Sector:}

- SDG 8: Promoting sustained, inclusive and sustainable economic growth, full and productive employment and work for all.

- SDG 12: Ensuring sustainable consumption and production patterns.

- SDG 17: Strengthening the Means of Implementation and Revitalizing the Global Partnership for Sustainable Development.

Note: Please refer to volumes I and II of the National Development Plan 2014 - 2018 to identify the country's full SDG targets.

In this order of ideas and under the premise that investment in infrastructure and innovation are fundamental engines for economic growth, to achieve the revitalization of river navigability in Colombia it is necessary to articulate the needs that have been diagnosed in development plans at the national and departmental level with potential projects that will generate solutions focused on closing gaps.

Therefore, to achieve this articulation, we propose to use the methodological proposal developed 
in the Science, Technology and Innovation Management (GECTI) of COTECMAR, which aims to identify portfolios of interregional projects for economic development and the use of the river aptitude in Colombia (Murcia, Salgado, Gil, Saravia, \& Ortega, 2018).

In this way, it will be possible to understand the nation's strategy, identify existing territorial needs, categorize, evaluate and select them in order to prioritize potential projects and finally submit for approval by the sponsors (departmental governors, for example) the various initiatives (such as those presented in section 2) that COTECMAR and the National Navy can offer to promote navigability by obtaining resources that need to be allocated to strengthen the infrastructure, connection, operation, promotion and institution components of the River Master Plan, impacting the country's goals as contemplated in the National Development Plan.

\section{Conclusions}

This work focused on showing the importance for State entities to assimilate and understand what is contemplated within the River Master Plan 2015, in order to promote the bases of a more competitive, clean, safe and beneficial river transport system for the social development of the country.

Likewise, emphasis was placed on the role that the Ministry of National Defense has played, with the National Navy and COTECMAR as the main references of this institution, in promoting navigability and generating potential proposals to close existing gaps in infrastructure, transport, health, education and social promotion, among others, in the country's coastal regions, hand in hand with the efforts made by the Ministry of Transport.

Within the different components that the River Master Plan has for the fulfillment of its main objectives (rehabilitate the river infrastructure and improve the governance of the transport system) this article explored the present contributions that the National Navy and COTECMAR have generated to dynamize the river development, exposing the case of the river piers, the River Information System (RIS) and the integration of the "Small Boats Committee".) Likewise, the potential contributions that these entities can make to the operational component were presented, based on the presentation of projects (multifunctional vessels) to address current problems. The contribution that can be made in Science, Technology and Innovation if the National Port Agency is structured was also highlighted.

Finally, the importance of articulating the National Development Plan, framed within the commitments acquired before the United Nations to comply with the Agenda 2030 for Sustainable Development, with all the other plans and strategies that the National Government draws up at the different ministerial levels (such as the River Master Plan) to close social gaps, was also highlighted. To this end, a methodological proposal used to structure interregional project portfolios to allow the different regions to allocate resources to solve common problems that slow down their economic growth is recommended.

\section{Bibliography}

ARMADA NACIONAL DE COLOMBIA. (2016). Plan Estratégico Naval 2015 - 2016. Bogotá.

DEPARTAMENTO NACIONAL DE PLANEACIÓN - DNP. (2015). Plan Nacional de Desarrollo 2014 - 2018, Todos por un Nuevo País. Tomo I y Tomo II. Bogotá: Imprenta Nacional de Colombia.

DNP , Ministerio de Transporte, ARCADIS, \& JESYCA S.A.S. (2015). Plan Maestro Fluvial. Bogota.

MINISTERIO DE DEFENSA NACIONAL. (2018). Contrato Interadministrativo No 0032-ARC-CBN6. Bogota.

MINISTERIO DE DEFENSA NACIONAL - 
Colombia. (2016). Plan Estratégico del Sector Defensa y Seguridad - Guía del Planeamiento Estratégico 2016 - 2018. Bogotá.

MINISTERIO DE DEFENSA NACIONAL. (2018). Contrato interadministrativo No 027-ARC-CBN6-2018. Bogota.

MINTRANSPORTE, DNP, ARCADIS, \& S.A.S, J. (2015). Plan Maestro Fluvial. Bogota.
Methodological Proposal for the Identification of an Interregional Project Portfolio for the Economic Development and Exploitation of Riverine Vocation of Colombia. Ship Science and Technology, 63-72.

NACIONES UNIDAS. (2017). Anexo: Marco de Indicadores Mundiales para los Objetivos de Desarrollo Sostenible y Metas de la Agenda 2030 para el Desarrollo Sostenible. Naciones Unidas.

MURCIA, H., SALGADO , A., GIL, C., SARAVIA, J., \& ORTEGA , M. (2018). 